DOI:

\title{
A Critical Overview of the Geometry of Fraud and a Model Proposal within the Framework of Situational Action Theory*
}

\author{
R. Şebnem YAŞAR**
}

\begin{abstract}
Geometric metaphors have been used in fraud theory for more than 60 years. The most commonly used of these metaphors is the fraud triangle. The fraud triangle has been criticized severely for its scope, substitutability of its elements, perceptuality, individuality and one-sidedness. Different models developed afterwards tried to cover the shortcomings of the fraud triangle with additions and modifications, but none of them became as popular as the fraud triangle. In this study, by moving away from the use of geometric metaphors, which has become a traditional approach in explaining the structure and causality of fraud, a model based on Situational Action Theory (SAT) is proposed. The aim of the study is to reveal that fraud has a complex and multi-dimensional structure that cannot be explained with one-dimensional metaphors, and in this context, to develop a theoretical model expressed in a mathematical formula for measuring fraud risk.

Keywords: Fraud, Fraud Theory, Fraud Triangle, Situational Action Theory.

JEI Classification: M40, M41, M42, M14.
\end{abstract}

\section{Hilenin Geometrisine Eleştirel Bir Bakış ve Durumsal Eylem Teorisi Çerçevesinde}

\section{Bir Model Önerisi}

\section{ÖZET}

Geometrik metaforlar 60 yılı aşkın bir süredir hile teorisinde kullanılmaktadır. Bu metaforlar içinde en yaygın kullanılanı hile üçgenidir. Hile üçgeni; kapsamı, unsurların ikame edilebilirliğini gözden kaçırması, algısalliğı, bireyciliği ve tek yönlülüğ̈̈yle oldukça sert eleştirilere maruz kalmıştır. Hile üçgeninden sonra geliştirilen farklı modeller, eklemeler ve modifikasyonlarla hile üçgeninin eksikliklerini kapatmaya çalışmış ancak hiçbiri hile ü̧̧geni kadar popüler olamamıştır. Bu çalışmada, hilenin yapısını ve nedenselliğini açıklamada geleneksel bir yaklaşım haline gelen geometrik metafor kullanımından uzaklaşılarak Durumsal Eylem Teorisi'ne (DET) dayalı bir model önerilmektedir. Çalışmanın amacı, hilenin tek boyutlu metaforlarla açıklanamayacak kadar karmaşık ve çok boyutlu bir yapıya sahip olduğunu ortaya koymak ve bu bağlamda hile riskini matematiksel bir formülle ölçen teorik bir model geliştirmektir.

Anahtar Kelimeler: Hile, Hile Teorisi, Hile Üçgeni, Durumsal Eylem Teorisi.

JEL Sınıflandırması: M40, M41, M42, M14.

\footnotetext{
* Makale Gönderim Tarihi: 31.08.2021, Makale Kabul Tarihi: 10.11.2021, Makale Türü: Kuramsal A preliminary version of this article has been presented at the 17th International Conference on Accounting held between 22-23 October 2020, and its extended abstract in Turkish has been published in conference proceedings. ** Assoc. Prof. Dr., Dokuz Eylül University, sebnem.yasar@deu.edu.tr, ORCID: 0000-0001-6173-5148
} 


\section{INTRODUCTION}

The Global Economic Crime and Fraud Survey (GECS) 2020 conducted by PricewaterhouseCoopers on more than 5000 companies in more than 99 countries reveals that accounting fraud rates which has been already high increased even more, and this situation threatens the well-being of companies. The total amount lost due to fraud in the last two years is over $\$ 42$ billion. $47 \%$ of the companies reported that they faced at least 1 fraud case in the last two years. The average number of fraud cases per company in the last two years is 6 and $26 \%$ of fraud actions were committed by senior management (PwC, 2020). The GECS 2020 report lays stress on the fact that companies will be at greater risk of having irreparable damage if essential control and prevention measures of fraud are not actualized effectively.

Fraud and other financial crimes are phenomena seen all over the world and they exist at the intersection point of law and accounting. The legal and social relativity of the framework in which the concept of fraud takes place creates border disputes in attempts to establish a universal definition of fraud and to determine its scope. Nevertheless, a general definition of fraud can be made as "a criminal violation of financial trust" (Cressey, 1953: 22). Fraudsters abuse the trust in their business environment in order to gain unlawful economic advantage for themselves and / or their organizations without using any physical force (Schuchter and Levi, 2015: 176). Edelhertz (1970) defines fraud as an illegal act or sequence of illegal actions committed through non-physical means, by concealment or guile, to obtain money or property, to avoid the payment or loss of money or property, or to gain business or personal advantage. Bozkurt (2009) takes the fraudster as the basis and defines fraud as the act of an employee gaining unfair advantage by using the assets and resources of the company of which s/he is a member, deliberately, secretly and improperly, and inflicting losses on the business in this way. Fraud also can be defined as a non-violent crime involving the theft of assets directly or indirectly through various deceptive methods such as "false accounting" (Power, 2013: 526). In International Standard on Auditing (ISA) 240, fraud is described as "an intentional act by one or more individuals among management, those charged with governance, employees, or third parties, involving the use of deception to obtain an unjust or illegal advantage” (ISA 240, parag. 6). Statement on Auditing Standards (SAS) No. 99 offers a more limited definition of fraud that is "an intentional act that causes significant errors in the financial statements subject to audit" (AU Section 316, parag. 5).

Geometric models are often used to reveal the causes of financial fraud. The most well-known and most widely used of these geometric models is the fraud triangle. This study aims to bring a critical approach to the geometric models used to explain fraud, especially the fraud triangle and to suggest a theoretical model expressed in a mathematical formula. This study contributes to the literature in two ways. First, it shows that the geometric fraud models developed until today, especially the fraud triangle, are insufficient to explain fraud. Second, it proposes a model that aims to turn fraud risk into a measurable concept.

The remainder of this paper is organized as follows. First, geometric approaches to fraud are discussed. Here, the fraud triangle is especially emphasized as it is the most used and most popular model. Then, criticisms directed to the fraud triangle are examined in five categories which are its scope, substitutability of its elements, perceptuality, individuality and one-sidedness. By emphasizing the necessity of multidimensional approaches in explaining the causality of fraud, a fraud model is formulated on the basis of Situational Action Theory 
(SAT), to ensure that personal characteristics, organizational structure and national cultural elements are considered together in the measurement of fraud risk. "Ethical work climate dimensions" of Victor and Cullen (1988) are used as the measure of organizational elements, and the "national culture dimensions" of Hofstede $(1984,2010)$ are used as the measure of national cultural elements. Finally, contributions and limitations of the study are discussed, and some future research avenues are suggested.

\section{GEOMETRY OF FRAUD}

Fraud triangle and other geometric shapes have been used in fraud theory for over 60 years. While discussing the geometry of fraud, it should not be forgotten that the geometric representation is only a visual aid, a conceptual metaphor, a model. Fraud triangle is the most popular of them insomuch that the fraud triangle was created first and then the fraud theory was built on the foundation of the fraud triangle (Huber, 2017: 36).

\subsection{Fraud Triangle}

Much of the current perception of causes of fraud is based on the fraud triangle. The concept of the fraud triangle was put forward by Edwin H. Sutherland (1940) who first used the term "white-collar crime" and Donald Cressey (1953). Cressey (1953), focusing on the conditions that allow individuals to violate ethical norms and commit their first fraudulent act, carried out interviews with prisoners convicted of embezzlement, and finally he identified three common threads, namely financial problem (pressure), opportunity, and rationalization. Although the fraud triangle was originally created as a model limited to embezzlement behavior, in the following years, it has become a valid approach for all kinds of financial fraud.

Although the fraud triangle is not used as a concept in the U.S. Generally Accepted Auditing Standards (GAAS) and International Standards on Auditing (ISA), the elements of the fraud triangle are specified as the conditions that must exist for fraud to occur. With the acceptance of the fraud triangle in the auditing standards, it became a rational, common-sense approach.

\subsection{Criticisms of the Fraud Triangle}

The basic idea in Cressey's work is that three elements (pressure, opportunity, and rationalization) must exist for fraud to occur. The emphasis of the fraud triangle can be summed up as follows: When a person who encounters unshareable financial problems perceives an opportunity, he can commit fraud with a morally defensible excuse. In other words, fraud stems from the accidental simultaneity of appropriate motivation and opportunity. The justifications and excuses used to make the fraudulent act reasonable are important and necessary as they ensure that the person does not see him/herself as a criminal.

The Association of Certified Fraud Examiners (ACFE), the world's largest anti-fraud organization and the leading provider of anti-fraud education and certification, making the fraud triangle its keystone, advocates the use of the fraud triangle as a standard method to investigate all kinds of financial frauds. Even though the American Institute of Certified Public Accountants (AICPA) does not use the term fraud triangle, SAS 99 adopted fraud 
triangle elements (AU Section 316, parag 7). Similarly, the elements of the fraud triangle are listed as the distinctive features of fraud in ISA 240 (ISA 240, App 1).

Despite all the efforts of ACFE and AICPA, the fraud triangle is subject to intense criticisms. Huber (2017) argues that ACFE provides a structure that is not actually based on facts and enforces it, and also criticizes AICPA for adopting fraud triangle elements and excluding other criminology-based perspectives (Huber, 2017: 43). Similarly, Lokanan (2015), Cooper et al. (2013) and Morales et al. (2014) state that the fraud triangle, which is used as a standard model, has become an ideology which reflects the interests of the authorities, particularly ACFE. Thus, fraud is limited to a problem that can be addressed by increasing the supervision of the individual, that makes the supervisory efforts of accountants and auditors essential and precious. According to Lokanan (2015), it makes sense for ACFE to embrace the fraud triangle because it is the raison d'etre of ACFE.

The proponents of the fraud triangle have confronted the criticisms mostly by ignoring them, and the fraud triangle continues to be the basis of the fraud theory that emerged nearly 60 years ago. In this study, criticisms made to the fraud triangle are grouped under five headings, which are explained below.

\subsubsection{Scope}

One of the criticisms made to the fraud triangle is that it does not encapsulate the premises of fraud and does not sufficiently capture the characteristics of white-collar crimes other than embezzlement (Dorminey et al., 2012b; Ramamoorti et al., 2009; Huber, 2017; Heath, 2008; Schuchter and Levi, 2016). Heath (2008: 595) and Schuchter and Levi (2016: 117) state that although financial pressure or motivation are seen as necessary for the existence of fraud, many fraud acts are committed by wealthy individuals who are in the upper management levels of the organization. This raises the question of why these highincome people, who occupy respectable white-collar positions, resort to cheating by taking too much risk for a marginal increase in their income, but the fraud triangle does not provide an answer. Huber argues that the fraud triangle cannot be applied to all financial frauds as Cressey's model is based on interviews with people convicted of embezzlement, so this triangle can only be called the "embezzlement triangle" (Huber, 2017: 31).

Different types of fraud may require different causes and circumstances. The reason why a person devises a crime may be different from the reason why the crime is committed, and the reason for the continuation of the crime may be completely different from these two (Schuchter and Levi, 2016). Stating that the generalization of the fraud triangle should be evaluated carefully, Donegan and Ganon (2008) argue that the fraud triangle cannot be applied to all types of frauds and emphasize that the fraud triangle should not be qualified as a "general theory of financial crime" that provides a universally valid explanation.

\subsubsection{Substitutability of the Elements}

Albrecht et al. (2012: 35) compared the elements of the triangle, pressure (motivation), opportunity and rationalization, with the fuel, heat and oxygen needed to start a fire. According to this analogy, elimination of any of these elements will make it impossible for fraud (or fire) to emerge. Although Schuchter and Levi (2016) do not dispute that all fire 
triangle elements are necessary to start a fire, they point out that all fraud triangle elements are substitutable and emphasize that this analogy overlooks the substitutability. In international auditing standards and literature on financial fraud, it is mostly presumed that all elements are necessary for financial crimes to take place. However, some studies show that this assumption is not valid for all cases. The fraud triangle can create the suitable environment for fraud. However, all elements can be substituted.

Romney et al. (1980) took a "cumulative" approach, concluding that fraudulent behavior occurs as a result of the combination of situational pressures, opportunity for fraud, and personal characteristics. In this model, fraudulent action may occur when the total strength or weight of these three variables contributing to the fraud reaches sufficient level. (Romney et al., 1980). Thus, for example, a very strong motivation can eliminate the need for rationalization, or a great opportunity can lead to fraudulent action without financial pressure. Schuchter and Levi (2016), in their empirical study with high profile fraudsters in Switzerland and Austria, concluded that only the "opportunity" element is mandatory. In the presence of an opportunity, fraud can occur without motivation and rationalization.

The fraud triangle can be a composition of certain conditions for fraud, but it does not mean that every element is a mandatory prerequisite. The problematic claim that every element is necessary can be attributed to the inadequate examination of the universal validity of the fraud triangle.

\subsubsection{Perceptuality}

Fraud triangle is an intuitive framework for explaining financial fraud and all of its elements are based solely on the perception of the perpetrator. First of all, the person must have a problem that (s)he thinks is unshareable, and the action that constitutes the crime should be perceived as a unique possibility of solving this problem. Pressure (or motivation) may occur only if these two conditions are met. Second, the person should perceive his or her position of trust as an opportunity. Finally, he or she must be able to neutralize his or her action by perceiving it as an act that is not bad, that is, to justify the crime by rationalizing it.

Among these three elements, the most criticized one is the financial problems that cannot be shared (Schuchter and Levi, 2016; Morales et al., 2014). Even though the problem can actually be shared with others and easily resolved, what matters here is the individual's perception. Even if the individual has been able to embezzle money for some time, he will only do so when faced with a problem that he or she thinks (s)he cannot "share" with anyone and therefore cannot get help from others. However, Cressey did not show interest in describing external factors that could illuminate why some problems may become unshareable. On the contrary, he argues that abuse of trust is due to the individual's perception of his/her problem as unshareable.

Opportunity is defined as a potential form of action made possible by a particular set of social conditions that are symbolically included in the individual's repertoire of behavioral possibilities (Coleman, 1987: 409). Therefore, individual's awareness of a potential course of action is compulsory for the emergence of an opportunity. Hence, the fact that existing conditions can become opportunities is entirely related to how the individual perceives them. 
According to Cressey (1953), rationalization is always present before the crime is committed. The data collection process on this subject can only take place after the individual commits a crime and is caught. Retrospective information received from criminals reflects the person's current perception of the past event. It is not possible to know whether the rationalization took place before, during or after the criminal act. Therefore, the possibility that the data on this subject is inaccurate and distorted opens the objectivity of the rationalization process to criticism (Klenowski et al., 2010; Morales et al., 2014).

\subsubsection{Individuality}

Cressey (1953), following Sutherland (1940), considered fraud to be an individual problem as the model is designed by examining embezzlement, a crime committed by a single person acting alone for financial gain. Sutherland (1940) puts the individual's status, profession, and organization in which (s)he is a member of at the very center of the whitecollar crime definition. Based on this limited view, Cressey (1950) defines white collar crime as an act of a person acting alone, motivated by personal gain, violating the financial trust that (s)he initially accepted in good faith. The individualized focus of this model diverts attention from different approaches and perspectives to fraud analysis and from various factors that may reveal fraud risk (Cooper et al., 2013; Donegan and Ganon, 2008; Dorminey et al., 2010; Gabbioneta et al., 2013; Morales et al., 2014; Lokanan, 2015; Weisburd et al., 2001; Free, 2015). Moreover, it does not provide a good basis for determining the likelihood of fraud in case of collaboration that is one of the main elements of complex frauds and financial crimes. Presenting fraud and fraud risk in such a way results in prioritizing control systems in organizational surveillance practices and urges auditors to focus on the individuals and look for fraud in areas with individual risks (Dorminey et al., 2010; Lokanan, 2015; Lokanan, 2018; Power, 2013). Giving great importance to internal control processes that focus on separation of duties does not always serve the purpose of preventing fraud.

\subsubsection{One-sidedness}

The fraud triangle has also been the target of various criticisms for ignoring social, organizational, and cultural factors and highlighting only individual factors that contribute to fraud (Lokanan, 2015; Trompeter et al., 2013; Morales et al., 2014; Cieslewicz, 2012). Cressey postulated that embezzlement was an act committed by individual financial incentives. This point of view appears quite clearly in his interpretation of cases he examined. All but one of the people in the cases Cressey examined were motivated by financial concerns. One person (case no: 77), on the other hand, committed the action thinking that he was not in the position he deserved (Cressey, 1953: 59). Although the case pointed to a range of social and organizational factors, Cressey ignored a broader explanation (Free and Murphy, 2015; Morales et al., 2014). Hence, according to the triangle, fraud is an issue at the intersection point of the individual and the organization without any social, cultural or organizational aspects.

\subsection{Different Designs, Different Geometric Shapes}

The fraud triangle is not the only geometric metaphor used to describe fraud. Based on the fraud triangle, different authors have created different shapes that describe fraud and reveal its causality by using some add-ons to increase the explanatory potential of the model 
and make it a modern fraud diagnostic tool. In other words, by adding different elements that are thought to be effective in the formation of fraud, they tried to respond to the shortcomings of the fraud triangle. These geometric models are the fraud cube (Doost, 1990), the fraud diamond (Wolfe and Hermanson, 2004), the organizational fraud triangle (Free et al., 2007), the triangle of fraud action (Albrecht et al., 2008) Crowe's fraud pentagon (Marks, 2009), the fraud square (Cieslewicz, 2010), the fraud pentagon (Goldman, 2010), the meta-model (Dorminey et al., 2012a, 2012b), another fraud pentagon (Sorunke, 2016), S.C.O.R.E model (Vousinas, 2019) which is also a pentagon and its extended hexagonal version S.C.C.O.R.E model (Vousinas, 2019). The fraud scale (Albrecht et al., 1984) and M.I.C.E (Kranacher et al., 2010), though not represented by geometric shapes, still require the existence of specific elements for fraud to exist. There are also models that do not take the fraud triangle as a basis but develop approaches with completely different perspectives to fraud. 3-C (Rezaee, 2002) and ABC (Ramamoorti et al., 2009) models incorporate social and organizational as well as personal factors. However, whether it is a derivative of the fraud triangle or a brand new approach, none of the later models have been adopted as much as the fraud triangle.

The models developed after the fraud triangle are shown as symbols in Figure 1. In fact, the common feature and consequently the common problem of all geometric models is that all elements within the scope of the model have to be exist in all fraud cases. Otherwise, the geometric shape cannot be completed, and the model cannot be formed. For example, in a fraud case where only two of the three elements are present, existence of a triangle cannot be claimed. The fact that all the elements that make up the edges (or corners) of the model are mandatory in order to create a geometric model makes the similar situation valid for all geometric shapes such as diamond, square, cube, pentagon, etc.

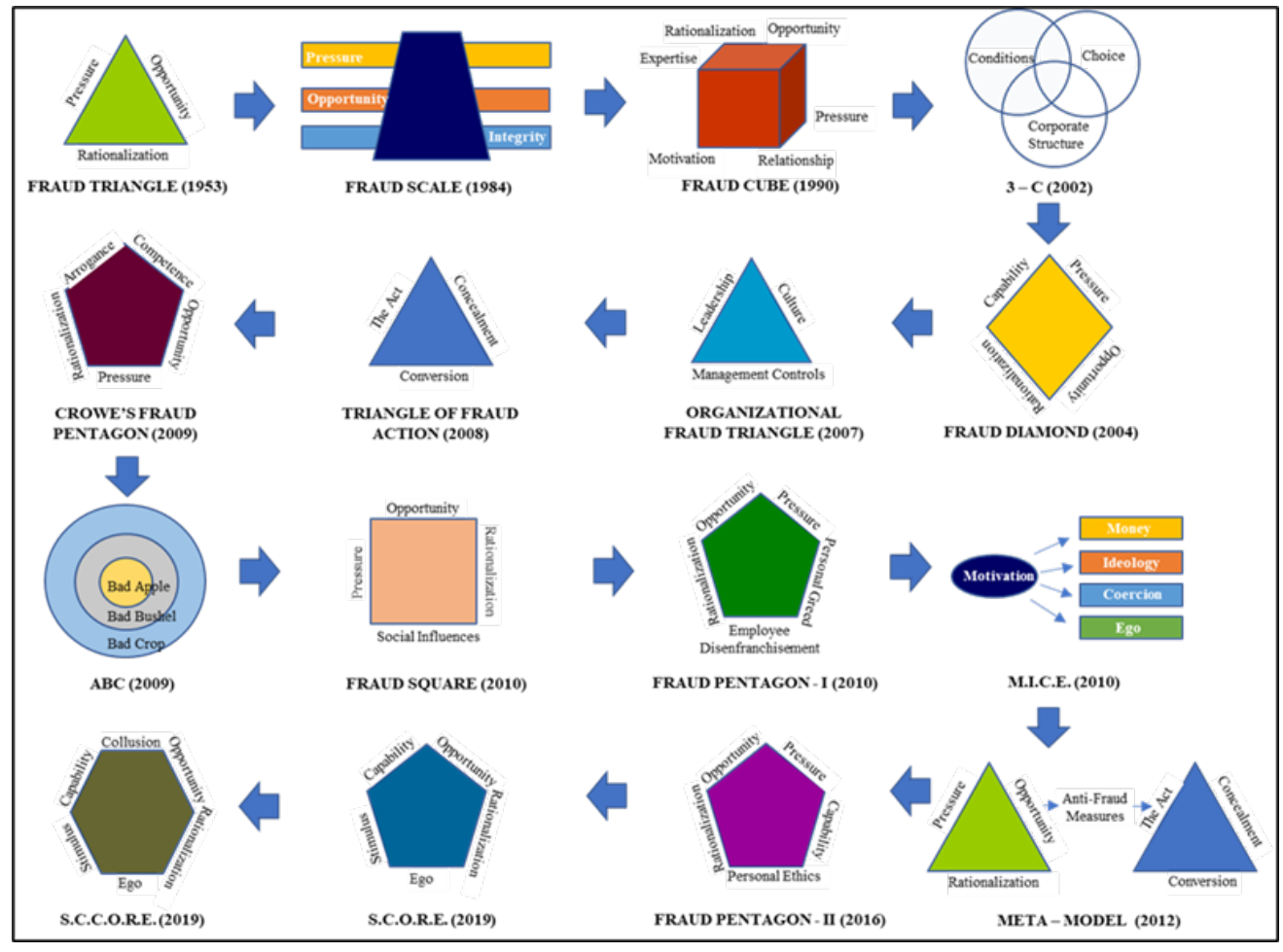

Figure 1. Symbolic Representations of Fraud Models 


\section{A MULTI-DIMENSIONAL APPROACH: SITUATIONAL ACTION THEORY}

With the widespread use of the fraud triangle, accounting and auditing research privileged psychological explanations and overlooked socio-political explanations of fraud and fraud risk. Thus, the emergence of fraud was based entirely on the character traits of the individual, with the focus being on seemingly perverted individuals who performed the action. As a result, organizational and social forces that foster fraud have been ignored for many years, and the role of organizational structure and social system has been assumed to be absent. However, in recent years, financial fraud has been defined as the result of social and organizational factors rather than individual deviance (Donegan and Ganon, 2008; Lokanan, 2015; Gabbioneta et al., 2013; Croall, 2001; Neu et al., 2013; Dellaportas, 2014; Cooper et al., 2013; Murphy and Dacin, 2011; Murphy, 2012; Schuchter and Levi, 2016; Palmer, 2012; Choo and Tan, 2007; Ferry and Lehman, 2018; Ashforth and Anand, 2003; Power, 2013; Free, 2015; Kaya and Ökten, 2014; Karabınar, 2005).

The complexity of fraud makes it difficult to deal with it with unidimensional causal theories. Cieslewicz (2012), Morales et al. (2014) and Lokanan (2016) argue that macro social, cultural and economic dimensions should be included in a fraud model. Differences in social and organizational culture play roles in regulating behavior. Although organizations act in their self-interest in capitalism, within different capitalist societies and also within different groups in the same society, there may be differences in what forms of doing business are acceptable or unacceptable (Schuchter and Levi, 2015: 177). The description of some practices as fraudulent, some immoral, some traditional and some innovative is closely linked to cultural ideology and discourse (Cooper et al., 2013: 446). Lokanan (2015) emphasizes that fraud should be considered as a socially structured phenomenon and accordingly situational and organizational factors should be a part of fraud discourse. Any fraud model should include the multifaceted and multidimensional qualities of fraud and should cover all the factors that contribute to facilitate and activate financial crimes.

Coleman (1989: 14-16) argues that individual crime stories that put a single person on the target board to which public anger will be directed ignore structural forces and claims that most of the financial crimes should be attributed not only to a single person and his/her personal and psychological conditions but also to social forces which are often overlooked. The social context in which fraud occurs is the result of a complicated process based on the interplay among individual, structural, and environmental factors (Cooper et al., 2013). This sociological view argues that fraud stems from social pressures rather than individual deviance. Almost everyone, especially politicians and executives, more or less lie, cheat and manipulate as required attitudes in organizational, social, and political life (Braithwaite, 2013: 458). In this context, fraud should be seen as a socially structured phenomenon. The behavior of the individual is embedded in organizational contexts shaped by the social pressure processes of actions towards mutual trade-off, social comparison, and adaptation. This organizational context can lead to a flow of misconduct by absorbing the individual (Gabbioneta et al., 2013: 486). From this perspective, fraud can be a phenomenon that is learned later. In summary, in the explanation of fraud, attention should be paid to the wider social context and how this social context shapes one's intellectual and moral development. 
There is a growing understanding that organizations and their economic environments are both context and potential tools for fraud to occur, providing not only opportunity but also reason (Power, 2013). Gross (1978: 56) suggests that organizations are criminogenic, that is, structures that cause crime by nature. Punch (1996: 84) makes a similar statement: "The organization is a tool, an environment, a justification, an opportunity for crime. The organization is both guilty and a victim at the same time." "Profit maximization", which is one of the basic mottos of companies operating in a capitalist environment, paves the way for the fraudulent activities performed for profitability to be described as "normal" or "should be". The economic, political, organizational, and cultural environment in which a company operates leads to the formation and acceptance of corporate and / or individual financial frauds.

Today, it is accepted that personal factors, and individual characteristics alone are not adequate to elucidate the way people behave, and studies are conducted on the effect of social factors on individual moral behavior. These approaches taking into account the elements around individuals define fraud as a prevalent affair practiced by rational actors whose behaviors are shaped by social and environmental forces to which they are exposed. Many people are subjected to different kinds of pressures and opportunities to cheat in their daily lives, yet a significant proportion still choose not to commit crimes. An important question is why some individuals take action to commit financial crimes and why others prefer not to behave likewise under similar conditions. To be able to answer these questions and explain financial fraud requires to focus on multi-dimensional approaches including situational action theory.

\subsection{Framework of Situational Action Theory (SAT)}

Situational Action Theory (SAT) is a multi-perspective approach that includes that has been developed by Wikström (2004) to overcome the distinction between individualist, structural, and environmental explicatory perspectives on the causes of crime by combining different approaches from criminology, social sciences, and behavioral sciences. SAT is a theory that explains crime as a moral act, and it aims to be a general theory of moral action that establishes the causes of crime (Wikström, 2004, 2010). The basic SAT model suggests that criminal acts occur as a result of the interaction of the individual's tendency to crime and his/her exposure to criminogenic environments. SAT's assumption is as follows (Wikström, 2010: 220):

\section{Crime $=$ Propensity $\times$ Exposure}

At the heart of this equation lies the idea that "people's actions are the result of a perception - choice process initiated and directed by person - environment interaction" (Wikström, 2004). A person's tendency to perceive crime as a choice of action is determined by his/her moral values and willpower. In this context, crime should be analyzed and explained as a moral act, that is, the choice to do or not to do right or wrong in certain situations. The process of making choices may be habitual or may require a thorough consideration on action options, depending on the individual's level of familiarity with the environment and conditions of that environment. Habitual action processes occur more frequently if the individual is familiar with the environment and conditions. However, if the individual is in an unfamiliar environment and conditions, the likelihood of the action being 
determined by the processes in which the action options are considered increases. SAT brings a different perspective towards crime by combining this dual selection process (based on habit or deliberation) and harmonizes the obvious discrepancies between individual and structural approaches (Lokanan, 2018).

According to SAT, main personal factors directly related to a person's criminal tendency are the moral values of the individual and his/her ability to control himself, in other words, his/her will. The main environmental factors that make the environment criminogenic are the moral rules of the environment and the implementation level of these rules (Wikström, 2010). Individual's morality and moral codes of an environment can prompt or prevent criminal activity.

\subsection{A Fraud Model Based on Situational Action Theory (SAT)}

Associating crime only with individuals' biological impulses, which are not sufficiently restricted by social control mechanisms is an extremely incomplete and inadequate approach and provides no basis for identifying non-biological conditions that cause deviations from expected behavioral patterns (Merton, 1938).

From the point of view of fraud, behaviors contrary to anticipated patterns are associated with cultural structure and organizational norms, and often these two elements work together. Cultural structure creates purposes or goals that individuals and organizations want to achieve, and the organizational structure determines, establishes, and controls the rules of acceptable ways to achieve these purposes or goals. What leads to the occurrence of fraud is how the concept of "acceptable" is defined. Although this concept is often compatible with ethical and legal rules, sometimes organizational structure can define the concept of "acceptable" differently and more broadly than legal and moral norms. In this context, organizational norms can sometimes explicitly allow fraud, and sometimes ignore it even if they do not explicitly allow.

Lokanan (2018) conducted a study demonstrating that financial fraud stems from a perception - choice process and is based on the interaction between the morality of the individual and the moral context (s)he is in. By presenting SAT as a framework capable of explaining accounting frauds and analyzing them as moral acts that people prefer to perform, he aims to shift the fundamentals of this issue to a wider area. Based on this presumption, it may be possible to turn fraud risk into a mathematical equation and free it from geometric metaphors. In this equation, fraud is formulated as the product of the individual's propensity for fraud and the individual's exposure to criminogenic environment.

Fraud $=$ Propensity for Fraud x Exposure to Criminogenic Environment

Propensity of the individual for fraud is determined by personal factors, that is, individual psychological elements. Criminogenity of the environment, that is the moral rules of the environment in which the individual lives and works and the level of application of these rules, is directly related to the organizational and cultural factors. So, the expansion of the multipliers of the formula can be made as follows:

Propensity for Fraud = Personal Factors 


\section{Exposure to Criminogenic Environment = Organizational Factors + Cultural Factors}

The multiplication operation in the equation ensures that in the absence of either of the two elements, the result is "0", that is, fraud does not occur. In other words, even if the individual is exposed to a highly criminogenic environment, fraud will not occur if (s)he is not prone to crime. Similarly, a person prone to crime will not be able to commit fraud if (s)he is not in a criminogenic environment. An individual with a low tendency to crime in a highly criminogenic environment will have a higher probability of fraud in order to adapt to the environment. On the other hand, an individual with a high tendency to crime in a low criminogenic environment will have a low probability of fraud.

\subsubsection{Personal Factors}

Personal factors are individual ethical values that help to set and maintain standards that describe "right" things to do in a situation. These consist of personality traits such as honesty, reliability, fairness, transparency, integrity, and conscientiousness. These ethical values influence individuals' choice and enable the person to support some actions and oppose others. The values, attitudes, and beliefs of individuals play an important role in determining which of the discourses, situations and demands that will arise in the business environment will be adopted immediately, which will be accepted hesitantly, and which will be rejected immediately (Coleman, 1987). The lack of ethical values or their presence at low levels can lead to crime because these people are more prone to commit crimes. For example, a person who lacks "social conscious" and believes that theft is an acceptable act is more likely to steal than a person who believes that theft is morally wrong.

The definition of fraud has been seen in the past more as "acts of individual moral deviation" and was considered as an abnormal phenomenon sustained by rational actors who make decisions without being affected by their situational contexts (Palmer, 2012). Fraud has also been associated with neurotic personality, Machiavellianism, greed, and fear of falling (Dorminey et al., 2010; Brody et al., 2012; Murphy and Dacin, 2011; Murphy, 2012; Albrecht et al., 2012).

One of the psychological characteristics associated with fraud that Heath (2008) emphasizes is greed. Typically, individuals involved in occupational fraud seek to enrich themselves personally, while companies that commit organizational fraud seek to improve their financial performance. Therefore, it can be generalized that all of them have a financial incentive. However, although the vast majority of individuals regularly face such incentives, they do not take advantage of the opportunity to commit a crime. Individuals who take advantage of these opportunities are greedy individuals who love money more than others (Heath, 2008). On the other hand, Coleman (1989) argues that what motivates white-collar criminals is not the desire for gaining more, but the fear of losing. This situation is also called "fear of falling". The underlying cause of fear of falling is the fear of losing the positions that people try hard to achieve or the income they work hard to gain (Wheeler, 1992; Piquero, 2012; Schuchter and Levi, 2016). When their achievements diminish and their decisions no longer lead to good results, they try to do whatever they can, including fraud, to save the day, while their position still allows it. 
At this point, it would be a misconception to conclude that personal factors are effective only in occupational fraud cases performed by the individual for his / her own benefit. The difference between occupational and organizational crimes is that occupational frauds are in the interest of the individual and organizational frauds are in the interest of the organization. However, this distinction does not show two distinct crime categories that are independent from each other. By definition, all white-collar crimes, whether occupational or organizational, occur when people with reputable positions seek financial gain while performing their profession and violate the law. In other words, organizational crimes are fraudulent acts carried out by the organization itself in line with the interests of the organization, but these actions are also performed by the members of the organization. Motivation for organizational crimes is often not the desire of individuals to help their organizations, but the personal rewards or benefits (performance bonus, promotion, not being fired, etc.) they will receive (Coleman, 1987). Therefore, all fraudulent activities (occupational or organizational) are directly linked to the ethical values of the person.

\subsubsection{Organizational Factors}

Each organization's working environment, rules, procedures, and the way the people in the organization do their jobs are unique. Dominant perceptions on organizational practices and procedures with ethical content create ethical working environment, and employees are aware of these patterns that exist in the organization. Organizational factors that expose their employees to a certain worldview provide a degree of isolation from the generally accepted definitions of social reality (Coleman, 1987: 422). In this context, in a decision-making process that will affect others, the "right" decision is defined in accordance with the ethical values and views of the organization and this decision does not have to be compatible with the individual's own moral or ethical values.

Various organizational conditions can encourage fraud. These include an unbalanced or very complex organizational structure, inappropriate management style or weakness of the top management, lack of personnel, lack of supervision and corporate governance, lack of or inadequate awareness of sensitivity training, negligence, and overly tolerant environment. In particular, as the control structure of the organization weakens, corporate governance becomes less efficient, and the quality of the control system breaks down. As a result, the opportunity for fraud increases. Strategic organizational goals depending on financial success and a rewarding system based on these goals without paying sufficient attention to the compliance of the applied methods with laws and internal rules increases the attractiveness and consequently the applicability of criminal behavior (Schuchter and Levi, 2015; Brennan and McGrath, 2007; Dellaportas, 2013).

The phenomenon of "administrative evil" occurs when ordinary people harm others or commit illegal acts while fulfilling their organizational responsibilities properly. This concept refers to structural disorders that naturalize, generalize, and socialize the bad and show that when the organization is abusive, the deterioration of the people within the organization is inevitable (Dillard and Ruchala, 2005: 609). Sometimes the belief in the sanctity of the company is so powerful that employees believe that as they serve the interests of the company, they also serve the interests of the whole society (Brief et al., 2001). The ethical internalization of an individual's sense of loyalty to the organization brings with it the imitation of the behavior (ethical or otherwise) of other members of the organization. 
Normalization refers to a process in which actions become commonplace over time and are carried out without question. The classification of the organizational practices as normal or fraud is decided by the actors in positions of authority (Lokanan, 2015). After fraud is deeply embedded in organizational systems and structures, certain practices that are seen as "normal" in the course of daily organizational life begin to be institutionalized (Murphy and Dacin, 2011; Ashforth and Anand, 2003). Ramamoorti et al. (2009: 9) give an example highlighting this situation: "If you'd asked Enron employees whether Enron was an ethical company or an unethical company, 90 percent would have said highly unethical. However, if the same employees were asked if they themselves were unethical individuals, they would have denied this claim.”

Falkenberg and Herremans (1995) revealed that informal systems within the organization are the primary factor on ethical behavior compared to formal systems. Informal systems create the ethical climate. In this study, Victor and Cullen's ethical work climate dimensions are used as the measure of organizational factors affecting the occurrence of fraud. Ethical climate theory (ECT), put forward by Victor and Cullen (1988), is unarguably one of the most forceful conceptual foundations in the field of business ethics. Work climates are the perceptions shared by the members of the organization regarding both formal and informal procedures, policies, and practices of the organization (Victor and Cullen, 1988; Martin and Cullen, 2006).

Victor and Cullen (1988) created a matrix by defining two dimensions that are ethical criterion and locus of analysis, each with three groups, and identified nine different types of ethical work climate. Considering that financial frauds are ethical deviations, these ethical work climates can be utilized in determining in which types of organizations realization potential of fraud is higher.

Ethical criterion dimension refers to the ethical criteria used in the decision-making processes of organizations. In this context, an organization can be "egoistic", "benevolent" or "principled". While egoistic organizations aim to maximize their own interests, benevolent organizations try to maximize common interests. For principled organizations, the priority is compliance with the rules. The ethical climate of an organization affects which ethical conflicts are to be taken into account, the process of resolving such conflicts, and the characteristics of the solutions. In an organization with a benevolent climate, an assessment of the well-being of other people is probably the prevailing reasoning used by organizational members to determine and solve ethical problems. In other words, decisions and actions that produce the best results for the greatest number of people take precedence. In a strongly principled climate, the implementation and interpretation of laws, rules and regulations are the prevailing forms of reasoning. On the other hand, in a largely egoistic environment, selfinterest take priority and maximizing it is the dominant thought.

Locus of analysis dimension includes reference groups that define the source of moral reasoning used to apply ethical criteria to organizational decisions and / or the limits on what to consider in ethical analysis of organizational decisions. It enables conceptualization of certain levels at which decision making takes place and behavior is operationalized. In this context, an organization can be "individual", "local" or "cosmopolitan". In the individual locus, the source of ethical judgment is the individual himself, whereas in the local locus it is the practices, rules and procedures within the organization. In the cosmopolitan focus, the 
source is the institutionalized normative system produced by a structure outside the organization, such as a professional or a legal body. What individual and cosmopolitan locuses have in common is that resources are located outside the organization.

The result of the intersection of these two dimensions is nine ethical climate types as shown in Figure 2. Each climate type stands for a different criterion for ethical decisionmaking.

\begin{tabular}{|l|l|c|c|c|}
\cline { 2 - 4 } \multicolumn{2}{c|}{} & \multicolumn{3}{c|}{ LOCUS OF ANALYS IS } \\
\cline { 2 - 5 } \multicolumn{2}{c|}{} & INDIVIDUAL & LOCAL & COSMOPOLITAN \\
\hline & Self-Interest & Company Profit & Efficiency \\
\hline & EGOISM & Friendship & Team Interest & Social Responsibility \\
\hline & BENEVOLENCE & Personal Morality & $\begin{array}{c}\text { Company Rules and } \\
\text { Procedures }\end{array}$ & $\begin{array}{c}\text { Laws and Professional } \\
\text { Codes }\end{array}$ \\
\hline
\end{tabular}

Figure 2. Ethical Work Climate Dimensions

Source: Victor and Cullen, 1988: 104

In the context of the egoism criterion, locus of analysis defines a certain "self" (e.g., individual, company) that is expected to act in line with its own interests. In the individual locus, the criterion of egoism refers to consideration of one's own needs and preferences (e.g., personal gain, self-defense), in the local locus to prioritizing the interests of the organization (e.g., corporate profit, strategic advantage), and in cosmopolitan locus to taking into account the interests of social and/or economic system (e.g., efficiency).

In the context of the benevolence criterion, locus of analysis defines the importance of "others" outside the organization for the members of the organization. This distinction and the associated responsibility to "others" distinguish benevolent organizations from the egoistic ones. In the individual locus, benevolence criterion means considering other people (e.g., friendship) without referring to organizational membership, while organizational integrity (e.g., team spirit) is considered in the local locus. In the cosmopolitan locus, benevolence means taking into account other parties outside the organization (e.g., social responsibility).

Principle criterion defines the sources of practices and principles in the organization. In the individual locus, it is expected to be guided by one's own ethical values. In the local locus, the source of the principles derives from the internal structure of the organization (e.g., rules and procedures). In the cosmopolitan locus, the source of the principles are the general binding rules formed outside the organization, such as the legal system and industrial regulations. In local and cosmopolitan organizational climates, the individual is guided by the sources, separate from himself and therefore independent of his/her personal ethical preferences.

In the individual locus, the individual takes decisions alone without organizational norms. Personal beliefs and values are the sources of decision-making criteria and moral reasoning. The individual egoistic work climate in which members of the organization strive 
to maximize their own interests offers the most favorable conditions for occupational frauds committed against the organization. In such organizations, internal control systems are often weak, management ineffective or overly tolerant.

On the other hand, the local egoistic climate may lead employees to fraud without thinking. In this climate type, employees are expected to do everything to raise company profits. Employees internalize that the policies and procedures must always be in line with the interests of the organization, and they usually get premiums based on actions aimed at protecting the interests of the organization, regardless of the consequences. This particular ethical climate emphasizes the importance of group membership in motivating and rewarding corruption within an organization (Murphy and Dacin, 2011; Cohen, 1995).

In subsequent empirical ECT studies, five ethical climate types frequently seen in organizations were determined, and these were named as instrumental, caring, independence, rules, and law and code (Martin and Cullen, 2006). The instrumental climate is the mergence of the individual egoistic climate with the local egoistic climate. In other words, it is the combination of two climate types that prioritize personal and organizational interests. In this climate type, employees are expected to prioritize decisions that provide personal benefits or serve the interests of the organization with little respect for ethical values (Martin and Cullen, 2006; Wimbush et al., 1997; Murphy and Free, 2016; Simha and Cullen, 2012; Hageman and Fisher, 2016). Employees in instrumental environments do not see any harm in making decisions that will benefit themselves or the organization, even if others will be harmed, and they perceive that this behavior is guided by the norms and / or expectations of the organization in line with organizational or personal interests (Murphy and Free, 2016; Martin and Cullen, 2006; Simha and Cullen, 2012). Organizations with instrumental ethical climate deserve a red flag just because they have this climate type.

\subsubsection{Cultural Factors}

Unethical behavior is by its nature a social phenomenon, as it consists of relationships between actors embedded in the structure of social relationships. Therefore, unethical behavior is linked to the different roles actors play in society and the relationships between actors that arise depending on these roles (Brass et al., 1998: 14-15). Various social circumstances can explicate why and how fraud occurs. Hence, exposure to criminogenic environment cannot be isolated from the cultural context of fraud. Taking into account the cultural factors and considering the structure of relationships between actors as cultural variables that have the potential to create (or prevent) fraud can help to understand and estimate the fraud risk in a particular cultural context.

A fundamental feature of social systems is that they contain a system of social norms that encompass values shared by primary groups of a nation. Values can be defined as "the tendency to prefer certain situations over others" (Hofstede, 1985: 347). Collective-level values represent culture versus individual-level values (Gray, 1988: 4). National culture refers to the preference of one behavior or one outcome over another and defines what is legitimate, right, and desirable in a given society. Therefore, it affects individuals' preferences and justifications. There are differences between perspectives and opinions among cultures as to which forms of inappropriate behavior in business life are acceptable and which are not. These differences affect the potential of employees and / or the organization to engage in 
fraudulent activities, the behavior of employees in situations that may be the indicative of fraud, and how society in general evaluates fraudulent activities. Therefore, the concept of fraud cannot be separated from the concept of national culture.

Studies have been conducted on the effect of the cultural factors on fraud. Choo and Tan (2007) explain the fraud risk in relation with Messner and Rosenfeld's (1994) American dream theory of crime. A fundamental idea of Messner and Rosenfeld's American dream theory is that the chase of financial success or quest of money dominates American society and besides that, non-economic institutions (e.g., educational, governing, family institutions) tend to serve the economy. This theory points to a widespread system of values and beliefs in the society dominated by large multinational corporations, where the goal of financial success is embraced by all. This basic assertion of American Dream theory helps to understand corporate frauds that provide monetary success especially to top management. Moreover, accompanying the goal of monetary success, a characteristic feature of the theory is to try to achieve American dream by "using all the means available". The persistence of capitalism requires appreciation of greed, that is one of the most fundamental human tendencies. This anomic tendency of the American dream provides a basis to understand and explain the implied approval of senior executives for corporate fraud (Choo and Tan, 2007). In almost all societies, albeit at different levels (individual or organizational) monetary success is a desired phenomenon that increases status, gives dignity, and positively affects the perspectives of others. According to Merton (1938), in cultures where achieving certain goals is the main criterion of personal value, individuals, especially those who think that values cannot be reached by legitimate means, are more inclined to violate and break legal and moral norms and rules than individuals in less goal-oriented cultures. In societies in which financial success is the basic criterion of personal value, and in which individualism, growth, and innovation are the basic cultural values, unethical behaviors and crime are expected to be higher.

Social capital indicates the nature of social networks and norms that enable the actions, particularly collaborative actions of individuals in a society. Studies show that higher levels of social capital lead to lower crime rates (Coleman, 1988; Halpern, 2001; Putnam, 1993). Although the relationship between social capital and financial frauds is indirect, still it can be a useful model to examine the effect of economic and social environments of individuals on their values, attitudes, and behaviors, and to understand the impact of environment on financial frauds (Trompeter et al., 2013: 295).

Hofstede (1984) described culture as "the collective programmed mind that separates the members of one group of people from another" and identified four dimensions of national culture that represent common structural elements of the cultural systems of countries. These are power distance, individualism versus collectivism, uncertainty avoidance, and masculinity versus femininity (Hofstede, 1984). Long-term orientation versus short-term orientation dimension was added to these four cultural dimensions in 1991, and the indulgence versus restraint dimension in 2010 (Hofstede et al., 2010). The relationship of each cultural dimension with fraud can be explained as follows:

- Power distance: Power distance is the extent to which individual members of a society acquiesce the fact that power is not equally distributed within institutions and organizations. In societies with high power distances, people usually accept a hierarchical 
structure in which everyone has a certain position without question. In contrast, in societies with low power distances, individuals strive to balance power and expect justifiable reasons for power inequality. The main point of this dimension is to examine how a society handles the inequality between individuals. The degree of power distance affects the structure of institutions and organizations in societies. In societies with high power distance, individuals feel that they are not taken seriously when making important decisions, which leads to a culture that is not participatory and more open to fraud. Also, in societies with high power distance, managers are more likely to influence financial reports with fraud and manipulation as they are less likely to be held accountable for their actions than in cultures with low power distance. In this context, it can be said that there is a positive relationship between power distance and fraud risk. (Doupnik, 2008; Mihret, 2014; Kaya and Ökten, 2014).

- Individualism versus collectivism: Individualism refers to a social structure that does not have close ties and points out that individuals in such a society prefer to look after themselves and their close family members only. Collectivism, on the other hand, refers to a tightly connected social structure and points out that an individual in such a society expects relatives or other group members to look after him/her in return for unquestioned loyalty. The main point of this dimension is to examine the level of interdependence of the members of a society. The assumption that fraud is the result of unshareable problem refers to an individualistic society. In this context, it can be concluded that as individualism increases, the possibility of unethical behaviors to be perceived as more acceptable also increases.

- Uncertainty avoidance: Uncertainty avoidance is the extent to which members of a society feel comfortable (or uncomfortable) with uncertainty and ambiguity. Societies with a high tendency to uncertainty avoidance have strict beliefs and codes of conduct and they try to control the future. These societies are also intolerant to dissenting people and ideas, and they feel uncomfortable being in such an environment. This feeling of discomfort leads individuals to beliefs that promise certainty or a definite result, and to cherish institutions that maintain harmony. On the other hand, in societies with a low tendency to uncertainty avoidance, there is a more comfortable environment in which practices are more important than principles. In these societies, anomalies are more easily tolerated, and they let the events flow. As the tendency to uncertainty avoidance increases, the tendency of individuals to act in conformity with the rules and regulations increases and the tendency to taking risks decreases. In this context, a positive relationship can be seen between risk taking tendency and unethical behavior that is as uncertainty avoidance increases, fraud risk decreases (Rallapalli et al., 1994; Mihret, 2014).

- Masculinity versus femininity: Masculinity means the preference of success, heroism, aggression, competitiveness and material power in a society. On the other hand, femininity means modesty, protecting the weak, preferring relationships and quality of life. Masculine societies contain most of the personality traits associated with fraud. This is supported by the research findings of Husted (1999) showing the significant positive relationship between masculinity and the acceptance of questionable behaviors as normal and ethical in business life.

- Long-term orientation versus short-term orientation: Long-term orientation shows the degree to which society prioritizes a future-oriented perspective rather than focusing on the present. The cultures with long-term orientation are characterized by patience, 
perseverance, sense of duty, respect for the elders, and obedience to the greater good. The short-term orientation leads individuals to spend and achieve rapid gains. Because individuals in long-term oriented cultures are more attached to organizational values, they are less likely to engage in dishonest behavior by surrendering to short-term motivations and pressures (Mihret, 2014). In this context, it can be concluded that there is a positive relationship between fraud risk and short-term orientation dimension.

- Indulgence versus restraint: In societies with high indulgence, individuals can freely fulfill their basic human needs, especially their passion for enjoying life and entertainment. In societies with a high tendency to restraint, individuals oppress their own needs under social norms. In this context, it can be said that there is a positive relationship between indulgence and fraud.

The structure leading to the tendency to fraud is quite complex and in order to understand this structure, national cultural characteristics should be considered as a variable. From the point of view of Hofstede's national culture dimensions, it can be concluded that fraud risk is highest in societies in which power distance, individualism, masculinity, shortterm orientation, and indulgence are high and uncertainty avoidance tendency is low.

\section{CONCLUSION AND FUTURE RESEARCH}

Over the years, both academic and professional literature have shown strong interest in the concept of fraud, which is the "dark side" of organizations. The fraud triangle has been used for many years as a structure that reveals the nature and causality of financial frauds. However, criticisms have increased especially in recent years that the fraud triangle does not cover all types of financial frauds, so it should not be the prevailing approach. Indeed, the fraud triangle, with its narrow scope, individualistic point of view and one-sided approach, cannot explain the concept of fraud, which has a complex and versatile structure. The fraud triangle ignores most of the elements and the mechanics of action that lead to the emergence of fraud, assuming the organizational and cultural structure is fixed. Although different models developed after the fraud triangle tried to complete these deficiencies, none of them were sufficient and found no widespread use. Fraud is a psychological, social, cultural and legal concept. The coexistence of so many elements in interaction with each other makes it very difficult to understand the reasons for fraud and to prevent it. Therefore, instead of focusing only on the fraud triangle, multidisciplinary approaches with better potential to elucidate the dynamics of white-collar crime should be taken into account.

In this study, by moving away from the use of geometric metaphors, a theoretical model that is based on SAT framework is proposed in which different elements can be included. The SAT equation is adapted to accounting frauds, and fraud risk is formulated as the multiplication of propensity for fraud and exposure to criminogenic environment. The propensity for fraud is assumed to be determined by personal factors, and criminogenity of the environment is assumed to be determined by organizational and cultural factors. The multiplication operation in the equation ensures that in the absence of any of the two elements, the result is " 0 ", that indicates no possibility for fraudulent activity. In other words, even if the individual is exposed to a highly criminogenic environment, fraud will not occur if (s)he is not prone to crime. Similarly, a person prone to crime will not be able to commit a crime and fraudulent action will not take place if (s)he is not in a criminogenic environment. 
However, these two situations are not very realistic. It is not possible for a person to have no tendency to cheat at all or for an environment to have "zero" criminogenity. Therefore, a more realistic interpretation may be that a person with a low tendency for fraud in a highly criminogenic environment will have a higher probability for fraud in order to adapt to the environment, while a person with a high propensity for fraud in a low criminogenic environment will have a considerably lower probability for fraud.

Ethical work climate dimensions of Victor and Cullen (1988) are used in the measurement of organizational elements, and cultural dimensions of Hofstede $(1984,2010)$ are used in the measurement of cultural elements. It is shown that the risk of organizational fraud is higher in the local egoistic climate type, and the risk of occupational fraud is higher in the individual egoistic climate type. The instrumental climate, which is the combination of these two climate types, provides the most suitable environment for all kinds of frauds. In terms of national culture, it can be said that the fraud risk is highest in individualistic, masculine, short-term oriented and indulgent societies with high power distance and low tendency to avoid uncertainty.

Studies on the impact of organizational culture on fraud risk are available in the literature, but the relationship between national culture and fraud has not received the same attention. Globalization has led to the internationalization of more companies. Therefore, the impact of national culture is an issue that needs to be considered in the context of fraud. Fraud can occur as a consequence of different motivations in different cultural contexts. In addition, the increase of multinational companies raises the question of what ethical principles the company will operate in. For example, if the cultural structure of the location of the home company is different from the cultural structure of the foreign country in which it operates, the question of according to which national culture the company will operate will become more of an issue. It can be investigated whether it needs to be structured in accordance with the culture of that country and what positive or negative effects of this situation may have on fraud risk.

The main aim of this study is to develop a theoretical model on fraud. In subsequent studies, scales that allow numerical measurement of fraud risk based on organizational and cultural structure can be developed. The Ethical Climate Questionnaire (ECQ) formulated by Victor and Cullen (1988), and then Cullen et al. (1993) or the Ethical Climate Index (ECI) developed by Arnaud (2006, 2010) can be used in the measurement of fraud risk based on organizational structure, or a completely different scale can be created. In the measurement of cultural factors, Hofstede's country scores related to cultural dimensions can be used. Although it is nearly impossible to convert a person's propensity for fraud into a numerical value, measuring the criminogenity of the environment will provide significant benefits in terms of determining fraud risk.

\section{REFERENCES}

Albrecht, W. Steve - Howe, Keith R. - Romney, Marshall B. (1984), Deterring Fraud: The Internal Auditor's Perspective, The Institute of Internal Auditors Research Foundation, Altamonte Springs.

Albrecht, W. Steve - Albrecht, Chad O. - Albrecht, Conan C. - Zimbelman, Mark F. (2012), Fraud Examination (4th Ed.), South-Western Cengage Learning, Ohio. 
American Institute of Certified Public Accountants (AICPA). (2002), AU section 316: Consideration of Fraud in a Financial Statement Audit. https://www.aicpa.org/research/standards/auditattest/downloadabledocuments/au00316.pdf

Arnaud, Anke (2006), “A New Theory and Measure of Ethical Work Climate: The Psychological Process Model (PPM) and the Ethical Climate Index (ECI)”, Doctoral Dissertation, University of Central https://commons.erau.edu/cgi/viewcontent.cgi?article=1010\&context=db-management

Arnaud, Anke (2010), “Conceptualizing and Measuring Ethical Work Climate: Development and Validation of the Ethical Climate Index", Business and Society, 49(2), pp. 345358.

Ashforth, Blake E. - Anand, Vikas (2003), "The Normalization of Corruption in Organizations", Research in Organizational Behavior, 24, pp. 1-52.

Bozkurt, Nejat (2009), İşletmelerin Kara Deliği Hile, Alfa Basım Yayın, İstanbul.

Braithwaite, John (2013), "Flipping Markets to Virtue with Qui Tam and Restorative Justice”, Accounting, Organization and Society, 38(6-7), pp. 458-468.

Brass, Daniel J. - Butterfield, Kenneth D. - Skaggs, Bruce C. (1998), "Relationships and Unethical Behavior: A Social Network Perspective”, Academy of Management Review, 23, pp. 14-31.

Brennan, Niamh M. - McGrath, Mary (2007), "Financial Statement Fraud: Some Lessons from US and European Case Studies”, Australian Accounting Review, 17(2), pp. 4961.

Brief, Arthur P. - Buttram, Robert T. - Dukerich, Janet M. (2001), "Collective Corruption in the Corporate World: Toward a Process Model”, In M. E. Turner (Ed.), Groups at Work: Theory and Research (pp. 471-499), Psychology Press, New York.

Brody, Richard G. - Melendy, Sara R. - Perri, Frank S. (2012), "Commentary from the American Accounting Association's 2011 Annual Meeting Panel on Emerging Issues in Fraud Research”, Accounting Horizons, 26(3), pp. 513-531.

Choo, Freddie - Tan, Kim (2007), "An "American Dream” Theory of Corporate Executive Fraud”, Accounting Forum, 31(2), pp. 203-215.

Cieslewicz, Joshua K. (2010), "The Fraud Square: Societal Influences on the Risk of Fraud", American Accounting Association Annual Meeting, San Francisco, USA.

Cieslewicz, Joshua K. (2012), "The Fraud Model in International Contexts: A Call to Include Societal-Level Influences in the Model”, Journal of Forensic \& Investigative Accounting, 4(1), pp. 214-254.

Cohen, Deborah V. (1995), "Ethics and Crime in Business Firms: Organizational Culture and the Impact of Anomie”, In F. Adler \& W. S. Laufer (Eds.), The Legacy of Anomie Theory: Advances in Criminological Theory, Vol. 6 (pp. 183-206), Transaction Publishers, New Jersey.

Coleman, James S. (1988), "Social Capital in the Creation of Human Capital", American Journal of Sociology, 94, pp. 95-120.

Coleman, James W. (1987), "Toward an Integrated Theory of White-Collar Crime", American Journal of Sociology, 93(2), pp. 406-439.

Coleman, James W. (1989), The Criminal Elite: The Sociology of White-Collar Crime (2nd ed.), St. Martin's Press, New York. 
Cooper, David J. - Dacin, Tina - Palmer, Donald (2013), "Fraud in Accounting, Organizations and Society: Extending the Boundaries of Research”, Accounting, Organizations and Society, 38(6-7), pp. 440-457.

Cressey, Donald R. (1950), "The Criminal Violation of Financial Trust”, American Sociological Review, 15, pp. 738-743.

Cressey, Donald R. (1953). Other People's Money: A Study in the Social Psychology of Embezzlement, The Free Press, Washington D.C.

Croall, Hazel (2001), Understanding White Collar Crime, Open University Press, Philadelphia.

Cullen, John B. - Victor, Bart - Bronson, James W. (1993), “The Ethical Climate Questionnaire: An Assessment of Its Development and Validity”, Psychological Reports, 73, pp. 667-674.

Dellaportas, Steven (2013), “Conversations with Inmate Accountants: Motivation, Opportunity and the Fraud Triangle”, Accounting Forum, 37(1), pp. 29-39.

Dillard, Jesse F. - Ruchala, Linda (2005), "The Rules Are No Game: From Instrumental Rationality to Administrative Evil”, Accounting, Auditing \& Accountability Journal, 18(5), pp. 608-630.

Donegan, James J. - Ganon, Michele W. (2008), "Strain, Differential Association, and Coercion: Insights from the Criminology Literature on Causes of Accountant's Misconduct”, Accounting and the Public Interest, 8(1), pp. 1-20.

Doost, Roger K. (1990), “Accounting Irregularities and Computer Fraud”, National Public Accountant, 35(5), pp. 36-39.

Dorminey, Jack W. - Fleming, Arron S. - Kranacher, Mary-Jo - Riley, Richard A. (2010), "Beyond the Fraud Triangle: Enhancing Deterrence of Economic Crimes", The CPA Journal, 80(7), pp. 17-24.

Dorminey, Jack W. - Fleming, Arron S. - Kranacher, Mary-Jo - Riley, Richard A. (2012a), "Financial Fraud: A New Perspective on an Old Problem", The CPA Journal. 82(6), pp. 61-65.

Dorminey, Jack W. - Fleming, Arron S. - Kranacher, Mary-Jo - Riley, Richard A. (2012b), "The Evolution of Fraud Theory", Issues in Accounting Education, 27(2), pp. 555579.

Doupnik, Timothy S. (2008), "Influence of Culture on Earnings Management: A Note”, Abacus, 44(3), pp. 317-340.

Edelhertz, Herbert (1970), The Nature, Impact, and Prosecution of White-Collar Crime, US Government Printing Office, Washington D.C.

Falkenberg, Loren - Herremans, Irene (1995), "Ethical Behaviours in Organizations: Directed by the Formal or Informal Systems?”, Journal of Business Ethics, 14(2), pp. 133-143.

Ferry, Laurence - Lehman, Glen (2018), "Trends in Corruption, Environmental, Ethical, and Social Accounting”, Accounting Forum, 42(1), pp. 1-2.

Festinger, Leon (1957), A Theory of Cognitive Dissonance, Stanford University Press, California.

Free, Clinton (2015), "Looking Through the Fraud Triangle: A Review and Call for New Directions”, Meditari Accountancy Research, 23(2), pp. 175-196.

Free, Clinton - Macintosh, Norman - Stein, Mitchell (2007), "Management Controls: The Organizational Fraud Triangle of Leadership, Culture, and Control in Enron”, Ivey Business Journal, July/August. 
https://iveybusinessjournal.com/publication/management-controls-the-organizationalfraud-triangle-of-leadership-culture-and-control-in-enron/

Free, Clinton - Murphy, Pamela R. (2015), “The Ties That Bind: The Decision to Co-Offend in Fraud”, Contemporary Accounting Research, 32(1), pp. 18-54.

Gabbioneta, Claudia - Greenwood, Royston - Mazzola, Pietro - Minoja, Mario (2013), "The Influence of the Institutional Context on Corporate Illegality”, Accounting, Organizations and Society, 38(6-7), pp. 484-504.

Goldman, Peter D. (2010), Fraud in The Markets: Why It Happens and How to Fight It, John Wiley \& Sons, New Jersey.

Gray, Sidney J. (1988), “Towards a Theory of Cultural Influence on the Development of Accounting Systems Internationally”, Abacus, 24(1), pp. 1-15.

Gross, Edward (1978), “Organizational Crime: A Theoretical Perspective”, In: N. K. Denzin (Ed.), Studies in Symbolic Interaction: Vol. 1, (pp. 55-85). JAI Press, Greenwich.

Hageman, Amy M. - Fisher, Dann G. (2016), “The Influence of Client Attributes and Organizational Climate on Tax Professionals", Research on Professional Responsibility and Ethics in Accounting: Vol. 20, (pp. 31-66). Emerald Group Publishing Limited, Bingley.

Halpern, David (2001), "Moral Values, Social Trust, and Inequality: Can Values Explain Crime?”, British Journal of Criminology, 41(2), pp. 236-251.

Heath, Joseph (2008), "Business Ethics and Moral Motivation: A Criminological Perspective”, Journal of Business Ethics, 83(4), pp. 595-614.

Hofstede, Geert (1984), “Cultural Dimensions in Management and Planning”, Asia Pacific Journal of Management, 1(2), pp. 81-99.

Hofstede, Geert (1985), “The Interaction between National and Organizational Value Systems”, Journal of Management Studies, 22, pp. 347-357.

Hofstede, Geert - Hofstede Gert J. - Minkov, Michael (2010), Cultures and Organizations: Software of the Mind. (3rd Ed.), McGraw-Hill, Maidenhead.

Huber, Dennis (2017), "Forensic Accounting, Fraud Theory, and the End of the Fraud Triangle”, Journal of Theoretical Accounting Research, 12(2), pp. 28-49.

Husted, Bryan W. (1999), "Wealth, Culture, and Corruption", Journal of International Business Studies, 30(2), pp. 339-359.

International Federation of Accountants (IFAC). (2008). International Standard on Auditing 240: The Auditor's Responsibilities Relating to Fraud in an Audit of Financial Statements.

https://www.ifac.org/system/files/downloads/2008_Auditing_Handbook_A080_ISA_2 40.pdf

Karabınar, Selahattin (2005), Kültür Muhasebe Etkileşimi Açısından Muhasebe İklimi: Muhasebeye Kültürel Bakışlar, Seçkin Yayınevi, Ankara.

Kaya, C. Tansel - Ökten, A. Begüm (2014), "Kültür Olgusunun Muhasebe Hileleri Üzerindeki Etkisi”, Journal of Accounting and Taxation Studies, 7(2), pp. 63-80.

Klenowski, Paul M. - Copes, Heith - Mullins, Christopher W. (2010), “Gender, Identity, and Accounts: How White Collar Offenders Do Gender When Making Sense of Their Crimes”, Justice Quarterly, 28(1), pp. 46-69.

Kranacher, Mary-Jo - Riley Jr., Richard A. Wells, Joseph T. (2011), Forensic Accounting and Fraud Examination, John Wiley \& Sons, New Jersey.

Lokanan, Mark E. (2015), “Challenges to the Fraud Triangle: Questions on Its Usefulness”, Accounting Forum, 39(3), pp. 201-224. 
Lokanan, Mark E. (2018), “Theorizing Financial Crimes as Moral Actions”, European Accounting Review, 27(5), pp. 901-938.

Marks, Jonathan (2009), "Playing Offense in a High-Risk Environment”, Crowe Horwath. https://vdocuments.mx/playing-offense-in-a-high-risk-playing-offense-in-a-high-riskenvironment-3.html

Martin, Kelly D. - Cullen, John B. (2006), "Continuities and Extensions of Ethical Climate Theory: A Meta-Analytic Review”, Journal of Business Ethics, 69, pp. 175-194.

Merton, Robert K. (1938), "Social Structure and Anomie”, American Sociological Review, 3(5), pp. 672-682.

Messner, Steven F. - Rosenfeld, Richard (1994), Crime and the American Dream, Wadsworth, Belmont.

Mihret, Dessalegn G. (2014), "National Culture and Fraud Risk: Exploratory Evidence”, Journal of Financial Reporting and Accounting, 12(2), pp. 161-176.

Morales, Jeremy - Gendron, Yves - Guénin-Paracini, Henry (2014), “The Construction of the Risky Individual and Vigilant Organization: A Genealogy of the Fraud Triangle”, Accounting, Organizations and Society, 39(3), pp. 170-194.

Murphy, Pamela R. - Dacin, M. Tina (2011), "Psychological Pathways to Fraud: Understanding and Preventing Fraud in Organizations”, Journal of Business Ethics, 101, pp. 601-618.

Murphy, Pamela R. (2012), "Attitude, Machiavellianism, and the Rationalization of Misreporting”, Accounting, Organizations and Society, 37(5), pp. 242-259.

Murphy, Pamela R. - Free, Clinton (2016), "Broadening the Fraud Triangle: Instrumental Climate and Fraud”, Behavioral Research in Accounting, 28(1), pp. 41-56.

Neu, Dean - Everett, Jeff - Rahaman, Abu Shiraz - Martinez, Daniel (2013), “Accounting and Networks of Corruption”, Accounting, Organizations and Society, 38(6-7), pp. 505524.

Palmer, Donald (2012), Normal Organizational Wrongdoing: A Critical Analysis of Theories of Misconduct in and by Organizations, Oxford University Press, Oxford.

Piquero, Nicole L. (2012), “The Only Thing We Have to Fear Is Fear Itself: Investigating the Relationship Between Fear of Falling and White-Collar Crime”, Crime \& Delinquency, 58(3), pp. 362-379.

Power, Michael (2013), “The Apparatus of Fraud Risk”, Accounting, Organizations and Society, 38(6-7), pp. 525-543.

Punch, Maurice (1996), Dirty Business: Exploring Corporate Misconduct, Sage Publications, London.

Putnam, Robert D. - Leonardi, Robert - Nonetti, Raffaella Y. (1993), Making Democracy Work: Civic Traditions in Modern Italy, Princeton University Press, Princeton.

PwC. (2020), PwC's Global Economic Crime and Fraud Survey. https://www.pwc.com/gx/en/forensics/gecs-2020/pdf/global-economic-crime-andfraud-survey-2020.pdf

Rallapalli, Kumar C. - Vitell, Scott J. - Wiebe, Frank A. - Barnes, James H. (1994), “Consumer Ethical Beliefs and Personality Traits: An Exploratory Analysis”, Journal of Business Ethics, 13, pp. 487-495.

Ramamoorti, Sridhar - Morrison, Daven - Koletar, Joseph W. (2009), "Bringing Freud to Fraud: Understanding the State-of-Mind of the C-Level Suite / White Collar Offender Through “A-B-C” Analysis”, University of Dayton, Accounting Faculty Publications, 71. 
Rezaee, Zabihollah (2002), Financial Statement Fraud: Prevention and Detection. John Wiley \& Sons, New York.

Romney, Marshall B. - Albrecht, W. Steve - Cherrington, David J. (1980), “Auditors and The Detection of Fraud", Journal of Accountancy, 149(5), pp. 63-69.

Schuchter, Alexander - Levi, Michael (2015), "Beyond the Fraud Triangle: Swiss and Austrian Elite Fraudsters”, Accounting Forum, 39(3), pp. 176-187.

Schuchter, Alexander - Levi, Michael (2016), “The Fraud Triangle Revisited”, Security Journal, 29(2), pp. 107-121.

Simha, Aditya - Cullen, John B. (2012), "Ethical Climates and Their Effects on Organizational Outcomes: Implications from the Past and Prophecies for the Future”, Academy of Management Perspectives, 26(4), pp. 20-34.

Sorunke, Olukayode A. (2016), "Personal Ethics and Fraudster Motivation: The Missing Link in Fraud Triangle and Fraud Diamond Theories”, International Journal of Academic Research in Business and Social Sciences, 6(2), pp. 159-165.

Sutherland, Edwin H. (1940), "White-Collar Criminality", American Sociological Review, 5(1), pp. 1-12.

Trompeter, Gregory M. - Carpenter, Tina D. - Desai Naman - Jones, Keith L. - Riley, Jr. Richard A. (2013), “A Synthesis of Fraud-Related Research”, Auditing: A Journal of Practice \& Theory, 32(1), pp. 287-321.

Victor, Bart - Cullen, John B. (1988), “The Organizational Bases of Ethical Work Climates”, Administrative Science Quarterly, 33(1), pp. 101-125.

Vousinas, Georgios L. (2019), “Advancing Theory of Fraud: The S.C.O.R.E. Model”, Journal of Financial Crime, 26(1), pp. 372-381.

Weisburd, David - Waring, Elin - Chayet, Ellen F. (2001), White-Collar Crime and Criminal Careers, Cambridge University Press, Cambridge.

Wheeler, Stanton (1992), “The Problem of White-Collar Motivation”, In K. Schlegel \& D. Weisburd (Eds.), White-Collar Crime Reconsidered (pp. 108-123). Northeastern University Press, Boston.

Wikström, Per-Olof H. (2004), "Crime as Alternative: Towards a Cross-Level Situational Action Theory of Crime Causation”, In J. McCord (Ed.), Beyond Empiricism: Institutions and Intentions in the Study of Crime: Advances in Criminological Theory (pp. 1-37), Transaction Publishers, New Brunswick.

Wikström, Per-Olof H. (2010), "Explaining Crime as Moral Actions”, In S. Hiltin \& S. Vaisey (Eds.), Handbook of the Sociology of Morality (pp. 211-239), Springer, New York.

Wimbush, James C. - Shepard, Jon M. - Markham, Steven E. (1997), “An Empirical Examination of the Relationship between Ethical Climate and Ethical Behavior from Multiple Levels of Analyses”, Journal of Business Ethics, 16, pp. 1705-1716.

Wolfe, David T. - Hermanson, Dana R. (2004), “The Fraud Diamond: Considering the Four Elements of Fraud, CPA Journal, 74(12), pp. 38-42. 